\title{
Hepatocellular Carcinoma (HCC) in Egypt: A comprehensive overview
}

\author{
Wafaa M. Rashed ${ }^{1 *}$ D, Mohamed Ahmed Mohamed Kandeil ${ }^{2}$, Mohamed O. Mahmoud ${ }^{3}$ and Sameera Ezzat ${ }^{4}$
}

\begin{abstract}
Background: Worldwide, hepatocellular carcinoma (HCC) is a universal problem and its epidemiological data showed variation from place to place. Hepatocellular carcinoma (HCC) is the sixth and fourth common cancer in worldwide and Egypt, respectively. Egypt ranks the third and $15^{\text {th }}$ most populous country in Africa and worldwide, respectively. The aim of this review is to compare the status of HCC in Egypt to that in the worldwide from different issues; risk factors, screening and surveillance, diagnosis and treatment, prevention, as well as research strategy.

Main body: The risk factors for HCC in Egypt are of great importance to be reported. The risk factor for HCC are either environmental- or host/genetic-related risk factors. In the last years, there is a tangible improvement of both screening and surveillance strategies of HCC in Egypt. The unprecedented national screening campaign launched by the end of 2018 is a mirror image of this improvement. While the improvement of the HCC prevention requires the governmental health administration to implement health policies. Although the diagnosis of Egyptian HCC patients follows the international guidelines but HCC treatment options are limited in terms of cost. In addition, there are limited Egyptian reports about HCC survival and relapse. Both basic and clinical HCC research in Egypt are still limited compared to worldwide.

Short conclusion: Deep analysis and understanding of factors affecting HCC burden variation worldwide help in customization of efforts exerted to face HCC in different countries especially large country like Egypt. Overall, the presence of a research strategy to fight HCC in Egyptian patients will help in the optimum allocation of available resources to reduce the numbers of HCC cases and deaths and to improve the quality of life.
\end{abstract}

Keywords: Hepatocellular carcinoma, Epidemiology, Screening and Surveillance, Prevention, Diagnosis and treatment, Research

\section{Background}

Worldwide, hepatocellular carcinoma $(\mathrm{HCC})$ is a universal problem and its epidemiological data showed variation from place to place. Egypt ranks the third and $15^{\text {th }}$ most populous country in Africa and worldwide, respectively. In Egypt, the health authorities consider HCC as the most challenging health problem. The number of HCC patients increased twofold over a decade [1]. The aim of this review is to compare the status of HCC in Egypt to that in the worldwide from different issues; risk factors, screening and surveillance, diagnosis and treatment, prevention, as well as research strategy. Deep understanding of these issues help in customization of

\footnotetext{
* Correspondence: wafaaanor@gmail.com

'Department of Research, Children's Cancer Hospital-57357, Cairo, Egypt

Full list of author information is available at the end of the article
}

efforts exerted to face HCC in different countries especially large country like Egypt.

\section{Epidemiology and disease burden in Egypt}

Hepatocellular carcinoma (HCC) represents the sixth most common cancer worldwide [2]. In Egypt, it represents the fourth common cancer [3]. Many hospitalbased studies $[1,4-6]$ reported increasing the incidence of HCC. The reason for increased incidence could be attributed to (1) improvement in screening programs and diagnostic tools [7], (2) increasing the survival rate of cirrhotic patients that increases the chance of developing $\mathrm{HCC}$, and (3) increasing the incidence and complications of hepatitis $\mathrm{C}$ virus (HCV) [4] which is the most important risk factor in developing liver cancer including HCC in Egypt [8]. 
Worldwide, HCC is the fourth most common cause of death from cancer [9]. It was estimated to be responsible for nearly $9.1 \%$ of the total deaths in $2012(746,000$ deaths) [10]. In Egypt, It is the most common cause of mortality- and morbidity-related cancer.

\section{Risk factors/etiology}

There are many risk factors that play an important role in the development of HCC. These risk factors are summarized in Table 1.

\section{(I) Environmental-related risk factors}

\section{Infectious risk factors}

Both hepatitis B virus (HBV) and hepatitis C virus (HCV) increase HCC risk by 20 -fold [11].

\section{(a) HBV infection}

Worldwide, HBV is one of the infectious risk factors of HCC. It accounts for $88 \%$ of cirrhosis-related HCC [12]. There are two patterns of HBV transmission: vertical transmission (from mother to newborns) and horizontal transmission (sexual and parenteral routes) [13]. $\mathrm{HBV}$ is oncogenic virus that integrates its genome in the host genome leading to both downregulation of tumor suppressor genes and activation of oncogenes [14]. In Egypt, there has been a decline in the prevalence of HBV infection over the last 20 years due to successful nationwide vaccination strategy $[15,16]$.

\section{(b) HCV infection}

Globally, HCV infection is the leading cause of cirrhosis (93\%) [12] which is a risk factor for HCC [17]. It induces both hepatic inflammation and fibrosis. Mutation and malignant transformation of the infected cells are promoted by the HCV protein expression [14, 18, 19]. $\mathrm{HCV}$ infection is characterized by its long time progression to cirrhosis-related HCC [20]. Based on the phylogenetic and sequence analyses of $\mathrm{HCV}$ genomes, there are seven genotypes of HCV strains and 67 subtypes upon further classification of each genotype [21]. $\mathrm{HCV}$ genotype 4 is considered the most predominant $\mathrm{HCV}$ genotype in Egypt [22]. In Egypt, HCV prevalence may be attributed to the initiation of the mass schistosomiasis treatment campaigns in the 1950 s and the 1960s [23]. Different HCV prevalence in Egypt were reported. The HCV prevalence in the age group (15-59 years) was $14.7 \%$ in 2008 while it became $10 \%$ in 2015 . This decline in prevalence was related to aging of infected people receiving anti-schistosomal injections [24, 25].

\section{Non-infectious risk factors}

Many environmental risk factors which is non-infectious play role in HCC risk.

\section{(a) Chemical compounds}

Occupational activities may include work exposure to a variety of chemical compounds. Liver is an important organ involved in detoxification, metabolic and excretory processes [26]. Therefore, HCC can be caused by the adverse effects of organic and inorganic chemical compounds exposure of the liver.

Inorganic compounds that may act as a risk factor for developing HCC include Arsenic [27] and Cadmium [28]. There are also number of organic compound $s[26$, $28]$ that may increase the risk of HCC. The most common are vinyl chloride monomer (VCM) and polyvinyl chloride (PVC) in addition to organic solvents (OS) that include trichloroethylene (TCE), perchlorethylene (PCE), $\mathrm{N}$-nitrosamines, dioxin-like compounds (DLC), polychlorinated biphenyls (PCB), and polybrominated biphenyls (PBB). In addition to chloral and chloral hydrates that were predominately used in DDT and other

Table 1 Risk factors for HCC development

\begin{tabular}{|c|c|c|c|}
\hline \multicolumn{2}{|l|}{ I-Environmental-related risk factors } & \multicolumn{2}{|l|}{ II-Host/genetic-related risk factors } \\
\hline $1-$ Infectious & $\begin{array}{l}\text { a)- HBV } \\
\text { b)- HCV }\end{array}$ & 1- Host-related risk factors & $\begin{array}{l}\text { a)- Gender } \\
\text { b)- Ethnicity } \\
\text { c)- Obesity } \\
\text { d)- Diet } \\
\text { e)- Oral contraceptives (OCs) } \\
\text { f)- Autoimmune Hepatitis } \\
\text { (Cryptogenic cirrhosis) } \\
\text { g)- Diabetes Mellitus } \\
\text { h)- NAFLD }\end{array}$ \\
\hline 2- Non-infectious & $\begin{array}{l}\text { a) Chemical compounds } \\
\text { b) Alcohol abuse } \\
\text { c) Smoking tobacco }\end{array}$ & 2- Genetic-related risk factors & $\begin{array}{l}\text { i)- Monogenic risk factors: } \\
\text { a)- Alpha } 1 \text { antitrypsin deficiency } \\
\text { b)- Hemochromatosis }\end{array}$ \\
\hline & & & $\begin{array}{l}\text { ii)- polygenic risk factors: } \\
\text { a)- Family history } \\
\text { b)- Aflatoxins }\end{array}$ \\
\hline
\end{tabular}


insecticides. The ortho-toluidine (O-toluidine) is used in herbicides and pesticides. In Egypt, about (26\%) of the population work in agriculture. This sector is at high risk for pesticides exposure and consequently high risk for developing $\mathrm{HCC}$ especially among rural males in addition to exposure to other risk factors (HBV and HCV) $[4,6,29,30]$. In mid delta region in Egypt, both pesticides and fertilizers have been suggested to be an independent risk factor for HCC [31].

(b) Alcohol

Chronic alcohol intake is one of the known risk factor for HCC in many countries but it is extremely low in Egypt $[6,29,30,32]$. The HCC risk increases by nearly five fold upon alcohol consumption of $>80 \mathrm{~g} /$ day ethanol for at least 5 years [33]. The underlying mechanism of developing HCC is complex and multi-factorial process [34].

\section{(c) Smoking}

In general, the tobacco ingredients are metabolized in liver and their carcinogenic effect is well-documented. Recently, a systematic review of 81 epidemiological studies [35] showed that there is an increase in the incidence of HCC risk and mortality among cigarette smokers. In Egypt, conflicting results were found regarding the association between tobacco smoking and the overall risk of HCC $[5,30,31]$.

\section{(II) Host-/genetic-related risk factors \\ 1. Host-related risk factors}

\section{(a) Gender}

There is gender variation of HCC incidence being the fifth most common cancer in men $(7.5 \%)$ and the ninth in women (3.4\%) [10]. In Egypt, HCC ranks the second and the sixth cancer in men and women, respectively [30]. This gender variation can be explained based on two reasons: biological reasons and environmental reasons. Biological reason for the variation of HCC incidence in women is explained by the level of estrogen hormone. It partially plays a role in suppression of interleukin (IL)-6-mediated inflammation that reduces both compensatory proliferation and liver injury [36]. Whereas testosterone in men can increase signaling of androgen receptors leading to promoting liver cell proliferation [37, 38]. This is in addition to variation in epigenetics and immune response. The environmental HCC incidence variation is explained by higher rate of men exposure to liver carcinogens such as occupational exposure to chemical compounds, alcohol and smoking in addition to hepatitis viral infection than women $[4,39]$

\section{(b) Ethnicity}

Worldwide, there is racial disparity of HCC rate among population living in the same region [13]. In general, the heterogeneous distribution of $\mathrm{HCC}$ at regional and international level can be explained on the basis of differences in both the prevalence and the acquisition period of key risk factors for liver diseases in general and HCC in particular $[1,8,32,40]$.

\section{(c) Obesity}

It is a metabolic defect defined as body mass index (BMI) $\geq 30 \mathrm{~kg} / \mathrm{m}^{2}$ and it is accompanied with an increase in the HCC risk by $89 \%$ [41, 42]. In Egypt, according WHO statistics 2008, there were approximately $46.3 \%$ females who are obese in comparison to $22.5 \%$ of males [30].

(d) Diet

Although a case-control study in Greece did not show any effect of diet (specific food category or certain nutrients) on the etiology of HCC [43], other studies showed this effect. An Italian case-control study [44] showed that there was an inverse relation between HCC risk and diet rich in both linoleic acid and $\beta$-carotene. Also, another Italian case-control study [45] showed the favorable effect of high intake of specific food for individuals at high risk for HCC. A Japanese study [46] among atomic bomb survivors showed 50\% reduction in HCC risk in those subjects whose diet was high in isoflavonerich miso soup and tofu. Research studies that investigate the association between diet and HCC risk in Egypt are lacking.

(e) Oral contraceptives

Although, there were two meta-analysis studies [47, 48] that investigated the association between HCC risk and oral contraceptives (OCs) use, the report showed inconclusive result about the association.

\section{(f) Autoimmune hepatitis}

Autoimmune hepatitis (AIH) is an immune-mediated inflammatory disease in liver. The association of $\mathrm{AIH}$ with limited polymorphisms at human leukocyte antigen (HLA) locus on chromosome 6p21.3 was confirmed. AIH progresses to cirrhosis which is the sine qua non for $\mathrm{HCC}$ with rate $1.1 \%$ in both sexes [42]. The curative treatment for both $\mathrm{AIH}$ and the underlying $\mathrm{HCC}$ is liver transplantation [49]. In Egypt, the incidence of HCC due to $\mathrm{AIH}$ is not available yet. 


\section{(g) Diabetes}

Many genome-wide association studies (GWAS) have identified many loci that affect the risk of type 2 diabetes $[50,51]$. There are many hypotheses [52] that explain the association between diabetes and the increased risk of HCC. Diabetes is one of the component of metabolic syndrome that may lead to non-alcoholic steatohepatitis (NASH) and consequently HCC. Also, persistent increase in insulin level in type 2 diabetic patients leads to both insulin resistance (IR) and an increase in the level of insulinlike growth factor-1 (IGF-1) in most tissues including liver that may accelerate carcinogenesis. In addition, chronic hyperglycemia may cause both oxidative stress and damage of hepatocytes. Also, a molecular mechanism involved in this association was observed upon detection of a p53 mutation (an apoptotic factor) in HCC diabetic patients compared to non-diabetics [53]. The prevalence of diabetes among HCC Egyptian patients has been reported by many studies $[4,5,30,54,55]$ and a study confirmed association of type 2 diabetes increases the risk of $\mathrm{HCC}$ by $2-$ 3 -fold [5]. In type 1 diabetes, its association with HCC risk is still controversial [56-58].

\section{(h) Nonalcoholic fatty liver disease}

It is characterized by abnormal increase of hepatic triglycerides (> 5\%) without extra alcohol intake [59]. In general, nonalcoholic fatty liver disease (NAFLD) increases the risk of HCC through developing NASH. In NASH patients, HCC is independent risk factor for mortality with hazard ratio $=7.9[60]$. Many genetic polymorphisms have been reported to be associated with NASH. In patients who have not consumed alcohol, NAFLD spectrum range from fatty liver to NASH that may end with cirrhosis. Worldwide, there are $20 \%$ of adults diagnosed with NAFLD, whereas up to $3 \%$ of adults are diagnosed with NASH [61]. In Egypt, an epidemiological study was conducted over 15 years on HCC patients and revealed that $5.3 \%$ of patients suffered from NASH [30]. This percentage is higher than the worldwide report.

\section{Genetic-related risk factors}

They are classified into monogenic and polygenic risk factors.

(i) Monogenic risk factors

\section{i. $\alpha 1$-Antitrypsin deficiency}

$\alpha 1$-Antitrypsin deficiency (A1ATD) is hereditary metabolic syndrome. It is an autosomal recessive disease that originate from several mutations in the SERPINA1 gene located on chromosome 14q32.1. It is characterized by abnormal accumulation of A1AT protein/ SERPINA1 in endoplasmic reticulum in the liver that damages hepatocytes causing cirrhosis and finally HCC $[49,62]$. It is associated with an increase in $\mathrm{HCC}$ risk especially in men [odds ratio $(\mathrm{OR})=5.0$ ] [63]. However, the exact prevalence of A1ATD among Egyptian patients has not been estimated.

\section{ii. Hereditary hemochromatosis or dietary iron overload}

It can lead to excessive accumulation of iron in liver and consequently affect adversely hepatocytes such as (chronic necroinflammatory hepatitis then fibrosis and in some cases causing cirrhosis). Hemochromatosis protein (HFE) in 90\% of hemochromatosis individuals is homozygous mutation at position 282 with substitution of tyrosine for cysteine (C282Y). HFE gene is positioned on chromosome $6 \mathrm{p} 21.3$ and is inherited as an autosomal recessive trait. Recent data suggests a 20 -fold increased risk of HCC among hereditary hemochromatosis patients [64]. In Egypt, the estimated prevalence of hereditary hemochromatosis is $0.5 \%$ [30].

\section{ii. Polygenic risk factors}

\section{(a) Family history of HCC}

The association of family history of HCC to the HCC risk has been reported through heritable factors and modified by environmental factors [65]. In Egypt, 21.4\% of HCC patients have a family history (first and second degrees relatives) of HCC [5].

\section{(b) Aflatoxins}

The global burden of aflatoxin-induced HCC ranges between 4.6 and 28.2\% [66]. There are many studies conducted in Egypt that confirmed the presence of both aflatoxin-albumin adducts in human blood $[67,68]$ and aflatoxin in food [69]. Aflatoxins are carcinogenic metabolites of certain fungi called Aspergillus flavus and Aspergillus parasiticum that contaminate many agricultural crops especially maize, peanuts, and cottonseed. The aflatoxins from these crops play an important role in the incidence of hepatocarcinogenesis worldwide [26, 28] and also in Egypt [70]. The World health organization (WHO) classified aflatoxins as group 1 carcinogen [71]. The most carcinogenic type of aflatoxin is Aflatoxin B1 (AFB1). The genetic hallmark of AFB1 exposure and HCC risk is a specific mutation as a single- 
base substitution at the third base of codon 249 in the TP53 gene. This mutation replaces an arginine by a serine (R249S) [72-74]. In addition, genetic polymorphism in the enzymes of activation (CYP enzymes) and deactivation (glutathione $S$-transferase) of pro-mutagenic aflatoxins may affect the level of pro-mutagenic aflatoxins and consequently the $\mathrm{HCC}$ risk [65].

It should be noted that immigration to Egypt after revolutions and wars in the Middle Eastern countries in the recent years may have an impact on all these risk factors. Screening for immigrants regarding the HCC risk factors, in general, and both HBV and HCV, in particular, should be encouraged.

\section{Screening and surveillance of HCC}

There are conflicting reports about the impact of HCC detection at an early stage on both the cure rate and the overall survival (OS) [11, 75]. Globally, HCC surveillance include both ultrasound and alpha fetoprotein (AFP) level measurement [76].

Several guidelines are available for screening high-risk populations including those diagnosed with cirrhosis and/or $\mathrm{HBV} / \mathrm{HCV}$ infection (with or without cirrhosis) [11]. Screening methods and surveillance intervals are the main differences between these guidelines. Although these guidelines affected greatly medical practice but due to poor adherence to screening, HCC mortality worldwide is increasing [11].

In Egypt, a national screening campaign was started by the Egyptian Ministry of Health (MOH) in 2018 to combat high HCV prevalence in Egypt by 2020 [77]. All screened participants with confirmed $\mathrm{HCV}$ infection are enrolled in government-subsidized treatment program using direct acting antiviral (DAA); sofosbuvir-based regimen. However, a nationwide campaign for HCC surveillance is still not available. Many studies showed conflicting results regarding the outcome of DAA treatment and $\mathrm{HCC}$ recurrence exit. Given the size of the $\mathrm{HCV}$ and $\mathrm{HCC}$ problems in Egypt, the HCV treatment program could yield important results on the efficiency of $\mathrm{HCV}$ treatment using DAA agents on HCC risk in the near future [78-81].

\section{Diagnosis and treatment approach Diagnosis}

During surveillance, finding a suspicious lesion using ultrasound in cirrhotic liver is followed by diagnostic confirmation using contrast enhanced helical computed tomography (CT) or dynamic magnetic resonance irradiation (MRI). Also, non-pathological confirmation of HCC diagnosis is achieved by AFP testing combined with previously mentioned imaging techniques [82].

\section{HCC treatment centres in Egypt}

There are seven types of centers that diagnose and treat HCC patients in Egypt:

1- Liver institutes that affiliated to Egyptian Ministry of Health (MOH), Universities, and Nongovernmental organizations (NGO).

2- Cancer centers affiliated to Egyptian $\mathrm{MOH}$ : there are ten specialized oncology center till now in nine governorates.

3- Cancer centers affiliated to Ministry of Higher Education.

4- Oncology/hepatology/tropical units in $\mathrm{MOH}$ and university hospitals.

5- NGO Cancer Centers: there is only one in the upper Egypt.

6- Military oncology Units that treat both military and civilian patients.

7- Private cancer centers and oncology clinics inside private hospitals.

The geographical distribution of these treatment centers all over Egypt should be assessed in relation to healthcare service provision, and the heterogeneity of patients' flow from different governorates. This will help in balanced geographical distribution of healthcare system.

\section{Treatment approach}

Precise staging of HCC initially is very useful for determination of the therapeutic options and the overall prognosis of the disease. There are certain clinical features upon which most staging systems use for HCC assessment. These clinical features are size and local extent of the tumor, metastasis of the tumor, severity of the liver disease, and the overall patient performance status [83]. There are two common staging systems; (a) American Joint Committee on Cancer (AJCC) TumorNode-Metastasis (TNM) [84] and (b) The Barcelona Clinic Liver Cancer (BCLC) system [84]. The first system characterizes both tumor features, lymph node involvement, and metastases. While the second system depends on the combination of tumor features, severity of the liver disease, and patient performance status. In comparison to other prognostic systems, BCLC system has the best correlation with the patient outcome [85]. Figure 1 represents different options for HCC therapeutic modalities used. Recently, results of studies for HCC treatment and prevention of complication have been reported [86-89]. Details about clinical trials in Egypt will be discussed in HCC research section.

The median overall survival (OS) of late diagnosis of HCC ranges between 6 and 20 months. In US, the 2and 5 -year OS were $<50 \%$ and $10 \%$, respectively [90]. In 


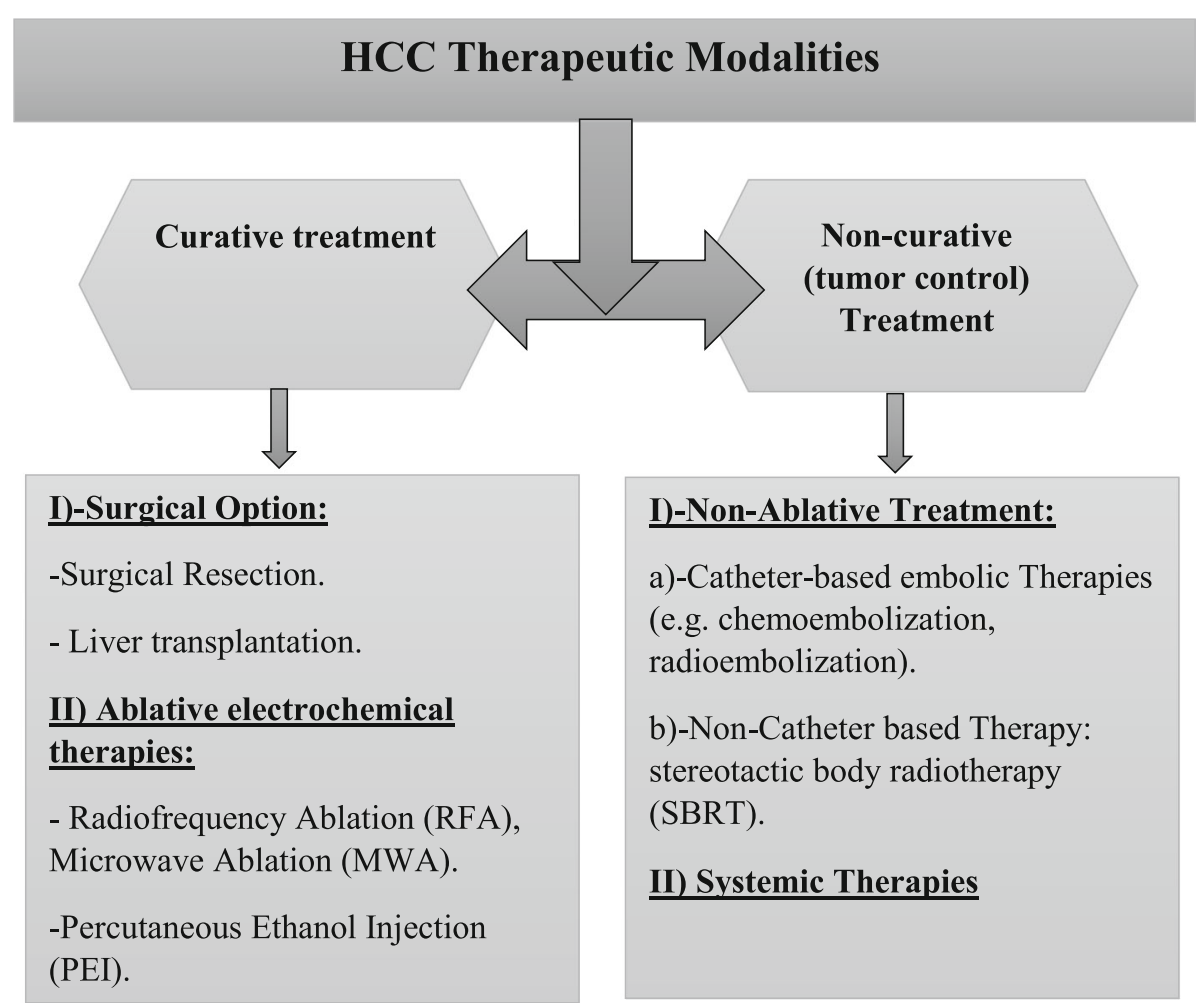

Fig. 1 Therapeutic modalities used for HCC treatment

Egypt, HCC survival and relapse are not reported extensively. The median OS of untreated HCC patients was 2.3 months [91]. Although all reports about the OS for treated HCC patients were slightly different but the OS is still poor [92, 93].

Many systemic cytotoxic chemotherapy drugs are used in HCC treatment as single agents, e.g.,: cisplatin, doxorubicin, 5-flurouracil, or combined regimen. All these chemotherapeutic agents are available in Egyptian market. These systemic treatments had three main disadvantages [94, 95]: (1) They have between 10 to $25 \%$ response rate with marginal survival improvement, (2) patients with underlying liver cirrhosis are poorly tolerating these treatments, and (3) $\mathrm{HCC}$ is highly resistance to single agent regimen.

Currently, there is paradigm shift in the HCC treatment by the introduction of immune checkpoint inhibitors in addition to molecular targeted therapies [96]. Many therapeutic agents for HCC are targets to different pathways implicated in hepatocarcinogenesis. Table 2 represents the list of FDA-approved targeted and immune therapies for HCC that are available in Egyptian market. In fact, there is an economical burden in the treatment of $\mathrm{HCC}$ in general and in using these expensive targeted therapies in particular. So, using targeted

Table 2 FDA-approved targeted and immune therapies for HCC

\begin{tabular}{llll}
\hline Generic drug & Brand name & Target & Availability in Egyptian \\
Cabozantinib & $\begin{array}{l}\text { Cabometyx and } \\
\text { Cometriq }\end{array}$ & Multikinase inhibitor & Available \\
Lenvatinib & Lenvima & Multikinase inhibitor & Available \\
Sorafenib & Nexavar & Multikinase inhibitor & Available \\
Regorafenib & Stivarga, and Regonix & Multikinase inhibitor & Available \\
Nivolumab & Opdivo & Immune check point inhibitors & Available \\
Pembrolizumab & Keytruda & Immune check point inhibitors & Available \\
Ramucirumab & Cyramza & Human monoclonal antibody against vascular endothelial growth factor & Available \\
& & 2(VEGFR 2) &
\end{tabular}


therapies in $\mathrm{HCC}$ treatment for Egyptian patients are limited to patients who can afford the cost.

\section{Prevention of HCC}

Clear determination of $\mathrm{HCC}$ risk factors is very helpful for well-designed strategies for HCC prevention. Generally, prevention of $\mathrm{HCC}$ is based on early prevention of HCC risk factors (primary prevention), treatment of risk factors at an early stage (secondary prevention), and preventing or decreasing HCC relapse after successful curative treatment (tertiary prevention) $[97,98]$.

There are different methods for HCC primary prevention. Routine HBV immunization to all newborns (within $24 \mathrm{~h}$ ) and high-risk groups is recommended by WHO [99]. This universal vaccination along with other behavioral pattern changes that decrease the risk of infection are very important primary prevention together with implementation of surveillance programs. In addition, antiviral treatment for chronic HBV and HCV patients is used for HCC secondary prevention [97, 98].

In Egypt, there are two methodologies for HCC primary and secondary prevention; HBV vaccination program [16], and, recently, HCV eradication through national campaign [77]. On the other hand, the principle of HCC prevention through education is the number one recommendation by World Gastroenterology organization's global guidelines [100]. Education intervention study as a pilot study had been conducted and showed promising results [101]. Designing an education-based intervention programs that show relation between the best preventive practice (e.g., pesticide handling and food storage) and HCC risk is highly needed. This is recommended especially for habitants of rural areas (high risk) [1].

In addition, HCC prevention should be supported by health care provider, patients, and health care system as a whole [98]. Each one has a definite responsibility. Health care provider who has a good knowledge should identify HCC risk factors and patients at risk then refer them for screening and surveillance. There is an Egyptian study that confirmed this role for academic physicians working in University Hospitals [102]. Patients should show compliance with health care provider recommendations. Furthermore, the health care system should have the capacity and responsibility to deliver surveillance tests. To sum up, it is the responsibility of governmental health administrations to implement health policies regarding HCC prevention.

\section{HCC research}

Hepatocellular carcinogenesis has been attributed to many biological aberrations, e.g., mutations, epigenetic dysregulations, and chromosomal anomalies. Six predominant molecular pathways have been identified in
HCC by whole-exome sequencing (WES). They include TERT promoter mutation, $\mathrm{Wnt} / \beta$-catenin, the P53 cellcycle pathway, epigenetic modifiers in histone methylation and chromatin remodeling, mutations in oxidative stress pathways (including NFE2L2 and KEAP1), PI3K/ AKT/mTOR, and RAS/MAPK pathways [103]. This is in addition to various molecular pathways that were recently discovered in a large study conducted on 363 HCC cases using WES and DNA copy number analysis and on 196 HCC cases using DNA methylation, RNA, miRNA, and proteomic expression [104]. Recently, Calderaro and colleagues proposed molecular and clinical features-based classification for HCC [105]. A recent systematic review identified 544 articles (16.2\%) published in PubMed about HCC in Egypt [106]. In Egypt, some abnormalities in molecular pathways involved in HCC have been identified $[107,108]$ but other abnormalities need to be identified on a large scale of HCC Egyptian patients using advanced technology. Identification of molecular characteristics of HCC Egyptian patients will pave the way for personalized therapy toward improvement of their overall survival [107].

\section{Clinical trials of $\mathrm{HCC}$}

Currently, in the era of precisian medicine, genomic profiling-based clinical trial has been started. NCIMATCH (ClinicalTrials.gov Identifier: NCT02465060) is the largest precision medicine that started in July 2015 [109]. It contains different targeted-therapies for each genetic abnormality arm/group in its design. It enrolls patients with specific "matching" genetic aberration and irrespective of their cancer type. Recently, $\mathrm{ComboMATCH}$ is another example of precisian trial that will be conducted but for combined targeted agents.

In Egypt, there are ten interventional clinical trials registered on clinicaltrials.gov (Table 3). Out of the ten clinical trials, there are four clinical trials that used targeted therapies; two of them were terminated. One of them (NCT01539018) showed no evidence of difference between treatments used. The other one (NCT01009593) was terminated by a recommendation from Independent Data Monitoring Committee (IDMC). The concept of clinical trials in Egypt is still limited that is why there is a low number of clinical trials in HCC.

In general, there is no structured national research program for HCC in place. The same notice was reported on liver research in Egypt [106]. There are many important research topics in HCC are still untouched deeply. The economic burden of HCC treatment and its relation to the health outcome, the effect of immigrants on HCC distribution in Egypt, the effect of diet on HCC risk, education-based intervention studies especially in rural area inhabitants (high risk), and molecular and 
Table 3 HCC clinical Trials in Egypt

\begin{tabular}{|c|c|c|c|c|}
\hline No. & Clinical trial number & Drug & Phase & Status \\
\hline 1 & NCT02715492 & LMWH & Phase 3 & Not yet recruiting \\
\hline 2 & NCT02771405 & •Drug: Sofosbuvir •Drug: Ribavirin $\bullet$ Drug: Simeprevir $\bullet$ Drug: daclatasvir $\bullet$ Drug: Ledipasvir & Phase 3 & Recruiting \\
\hline 3 & NCT03551444 & Administration of DAA-based treatment & Phase 3 & Recruiting \\
\hline 4 & NCT02971696 & -Drug: Sorafenib $\bullet$ Drug: Best Supportive care & Phase 3 & Completed \\
\hline 5 & NCT03151213 & •Drug: Pregabalin $150 \mathrm{mg} \cdot$ Other: Placebo & Phase 3 & Recruiting \\
\hline 6 & NCT02646137 & $\begin{array}{l}\text {-Drug: Transarterial chemoembolization (TACE) •Procedure: Radiofrequency } \\
\text { ablation combined with TACE } \bullet \text { Procedure: Microwave ablation combined with TACE }\end{array}$ & Phase 3 & Recruiting \\
\hline 7 & NCT01539018 & -Drug: Sorafenib $\bullet$ Drug: sorafenib plus tegafur-uracil & Phase 2 & Terminated \\
\hline 8 & NCT02568748 & •Biological: CIK •Procedure: TACE & Phase 3 & Recruiting \\
\hline 9 & NCT01655693 & -Drug: Doxorubicin $\bullet$ Drug: Best Standard of Care & Phase 3 & Active, not recruiting \\
\hline 10 & NCT01009593 & -Drug: ABT-869/Linifanib • Drug: Sorafenib & Phase 3 & Terminated \\
\hline
\end{tabular}

epigenetic characteristics of HCC in Egyptian patients are good examples for these research topics.

Research in HCC can be stimulated at many levels. On the institutional level, forming coordinated multidisciplinary research team who will study different aspects of HCC (epidemiological, diagnostic, treatment, and palliation aspects). On national level, establishing Egyptian Research Network for HCC (EARN HCC) is highly recommended. It will ease linking between different HCC specialized institutions to foster application of their respective expertise accumulated over years. On the international level, collaboration between Egyptian institutions and peer international specialized HCC institutions in different domains (training, twining research) should be supported by government health administration.

\section{Conclusion}

Hepatocellular carcinoma (HCC) is a universal problem and its epidemiological data showed variation from place to place. Deep analysis and understanding of factors affecting HCC burden variation worldwide help in customization of efforts exerted to face HCC in different countries especially large country like Egypt.

\footnotetext{
Abbreviations

A1ATD: a1-antitrypsin deficiency; AFB1: Aflatoxin B1; AFP: Alpha fetoprotein; AlH: Autoimmune hepatitis; AJCC: American Joint Committee on Cancer; BCLC: The Barcelona Clinic Liver Cancer system; BMI: Body mass index; CT: Computed tomography; DAA: Direct acting antiviral; DLC: Dioxin-like compounds; EARN HCC: Egyptian Research Network for HCC;

GWAS: Genome-wide association studies; HBV: Hepatitis B virus; HCC: Hepatocellular carcinoma; HCV: Hepatitis C virus;

HFE: Hemochromatosis protein; HLA: Human leukocyte antigen; IDMC: Independent Data Monitoring Committee; IGF-1: Insulin-like growth factor-1; IL: Interleukin; IR: Insulin resistance; $\mathrm{MOH}$ : Ministry of Health; MRI: Magnetic resonance irradiation; NAFLD: Nonalcoholic fatty liver disease; NASH: Non-alcoholic steatohepatitis; NGO: Non-governmental organizations; OCs: Oral contraceptives; OS: Overall survival; O-toluidine: Ortho-Toluidine; PBB: Polybrominated biphenyls; PCB: Polychlorinated biphenyls; PCE: Perchlorethylene; PVC: Polyvinyl chloride; TCE: Trichloroethylene; TNM: Tumor-node-metastasis; VCM: Vinyl chloride monomer; WES: Wholeexome sequencing; WHO: World Health Organization
}

\section{Acknowledgments}

The authors thanks Mohamed H. Abdel Rahman (Department of Ophthalmology, Ohio State University, Wexner Medical Center, Columbus, $\mathrm{OH}$, United States) for helpful comments and suggestions.

\section{Authors' contribution}

MAKQ, MOM, and SE proposed the design of the work. They did a critical review of the manuscript. WMR did the literature review and data curation. She was a major contributor in writing the manuscript. All authors have read and approved the manuscript.

\section{Funding}

None.

\section{Availability of data and materials}

Not applicable.

Ethics approval and consent to participate

Not applicable.

\section{Consent for publication}

Not applicable.

\section{Competing interests}

The authors declare that they have no competing interests.

\section{Author details}

${ }^{1}$ Department of Research, Children's Cancer Hospital-57357, Cairo, Egypt. ${ }^{2}$ Department of Biochemistry, Faculty of Veterinary Medicine, Beni-Suef University, Beni-Suef, Egypt. ${ }^{3}$ Department of Biochemistry, Faculty of Pharmacy, Beni-Suef University, Beni-Suef, Egypt. ${ }^{4}$ Department of Epidemiology and Prevention Medicine, National Liver Institute, Menoufia University, Menoufia, Egypt.

Received: 15 October 2019 Accepted: 2 January 2020

Published online: 16 January 2020

\section{References}

1. El Zayadi A-R, Badran HM, EMF B, Attia Mel- D, Shawky S, Mohamed MK et al. Hepatocellular carcinoma in Egypt: a single center study over a decade. World J. Gastroenterol. 2005;11:5193-8.

2. Forner A, Reig M, Bruix J. Hepatocellular carcinoma. Lancet. 2018;391:130114. https://doi.org/10.1016/S0140-6736(18)30010-2.

3. Akinyemiju T, Abera S, Ahmed M, Alam N, Alemayohu MA, Allen C, et al. The burden of primary liver cancer and underlying etiologies from 1990 to 2015 at the global, regional, and national level. JAMA Oncol. 2017:3:168391. https://doi.org/10.1001/jamaoncol.2017.3055.

4. Abd-Elsalam S, Elwan N, Soliman H, Ziada D, Elkhalawany W, Salama M, et al. Epidemiology of liver cancer in Nile delta over a decade: a single-center study. South Asian J Cancer. 2018;7:24. https://doi.org/10.4103/sajc.sajc_82_17. 
5. Ziada DH, El Sadany S, Soliman H, Abd-Elsalam S, Salama M, Hawash N, et al. Prevalence of hepatocellular carcinoma in chronic hepatitis $\mathrm{C}$ patients in Mid Delta, Egypt: a single center study. J Egypt Natl Canc Inst. 2016;28: 257-62. https://doi.org/10.1016/j.jnci.2016.06.001.

6. Ezzat S, Abdel-Hamid M, Eissa SA-L, Mokhtar N, Labib NA, El Ghorory L, et al. Associations of pesticides, HCV, HBV, and hepatocellular carcinoma in Egypt. Int J Hyg Environ Health. 2005;208:329-39.

7. El Serag HB. Epidemiology of hepatocellular carcinoma. Clin. Liver Dis. 2001; 5:87-107, vi.

8. Ibrahim AS, Khaled HM, Mikhail NN, Baraka H, Kamel H. Cancer incidence in Egypt: results of the national population-based cancer registry program. J Cancer Epidemiol. 2014;2014:437971. https://doi.org/10.1155/2014/437971.

9. Villanueva A. Hepatocellular Carcinoma. N Engl J Med. 2019;380:1450-62. https://doi.org/10.1056/NEJMra1713263.

10. Ferlay J, Soerjomataram I, Dikshit R, Eser S, Mathers C, Rebelo M, et al. Cancer incidence and mortality worldwide: Sources, methods and major patterns in GLOBOCAN 2012. Int J Cancer. 2015;136:E359-86. https://doi.org/ 10.1002/ijc.29210.

11. Zhao C, Nguyen MH. Hepatocellular Carcinoma Screening and Surveillance. J Clin Gastroenterol. 2016;50:120-33. https://doi.org/10.1097/MCG. 0000000000000446

12. Yang JD, Kim WR, Coelho R, Mettler TA, Benson JT, Sanderson SO, et al. Cirrhosis is present in most patients with hepatitis $B$ and hepatocellular carcinoma. Clin Gastroenterol Hepatol. 2011;9:64-70. https://doi.org/10. 1016/j.cgh.2010.08.019.

13. El Serag HB, Rudolph KL. Hepatocellular carcinoma: epidemiology and molecular carcinogenesis. Gastroenterology. 2007;132:2557-76. https://doi. org/10.1053/j.gastro.2007.04.061.

14. Tang A, Hallouch O, Chernyak V, Kamaya A, Sirlin CB. Epidemiology of hepatocellular carcinoma: target population for surveillance and diagnosis. Abdom Radiol (NY). 2018:43(1):13-25. https://doi.org/10.1007/s00261-017-1209-1.

15. Allison RD, Teleb N, Al Awaidy S, Ashmony H, Alexander JP, Patel MK. Hepatitis B control among children in the Eastern Mediterranean Region of the World Health Organization. Vaccine. 2016;34:2403-9. https://doi.org/10. 1016/j.vaccine.2016.03.063.

16. Salama II, Sami SM, Said ZNA, El-Sayed MH, El Etreby LA, Rabah TM, et al. Effectiveness of hepatitis $B$ virus vaccination program in Egypt: multicenter national project. World J Hepatol. 2015;7:2418-26. https://doi.org/10.4254/ wjh.v7.i22.2418.

17. Mohamed AA, Elbedewy TA, El-Serafy M, El-Toukhy N, Ahmed W, Ali El Din Z. Hepatitis C virus: a global view. World J Hepatol. 2015;7:2676-80. https:// doi.org/10.4254/wjh.v7.i26.2676.

18. El-Houseini ME, Ismail A, Abdelaal AA, El-Habashy AH, Abdallah ZF, Mohamed MZ, et al. Role of TGF- $\beta 1$ and C-Kit mutations in the development of hepatocellular carcinoma in hepatitis $C$ virus-infected patients: in vitro study. Biochem (Mosc). 2019;84:941-53. https://doi.org/10. 1134/S0006297919080108

19. Neamatallah M, El-Bendary M, Elalfy H, Besheer T, El-Maksoud MA, Elhammady D, et al. Impact of toll-like receptors 2(TLR2) and TLR 4 gene variations on HCV susceptibility, response to treatment and development of hepatocellular carcinoma in cirrhotic HCV patients. Immunol Invest. 2019:115. https://doi.org/10.1080/08820139.2019.1673772.

20. Freeman A, Dore GJ, Law MG, Thorpe M, Von Overbeck J, Lloyd AR, et al. Estimating progression to cirrhosis in chronic hepatitis $\mathrm{C}$ virus infection. Hepatology. 2001;34:809-16. https://doi.org/10.1053/jhep.2001.27831.

21. Kumar A, Rajput MK, Paliwal D, Yadav A, Chhabra R, Singh S. Genotyping \&amp; diagnostic methods for hepatitis $C$ virus: a need of low-resource countries. Indian J Med Res. 2018;147:445-55. https://doi.org/10.4103/ijmr. IJMR_1850_16.

22. Ray SC, Arthur RR, Carella A, Bukh J, Thomas DL. Genetic Epidemiology of Hepatitis C virus throughout Egypt. J Infect Dis. 2000;182:698-707. https:// doi.org/10.1086/315786.

23. Frank C, Mohamed MK, Strickland GT, Lavanchy D, Arthur RR, Magder LS, et al. The role of parenteral antischistosomal therapy in the spread of hepatitis C virus in Egypt. Lancet. 2000;355:887-91. https://doi.org/10.1016/ s0140-6736(99)06527-7.

24. Gomaa A, Allam N, Elsharkway A, El Kassas M, Waked I. Hepatitis C infection in Egypt: prevalence, impact and management strategies. Hepat Med. 2017; 9:17-25. https://doi.org/10.2147/HMER.S113681.

25. Kandeel A, Genedy M, El-Refai S, Funk AL, Fontanet A, Talaat M. The prevalence of hepatitis C virus infection in Egypt 2015: implications for future policy on prevention and treatment. Liver Int. 2017;37:45-53. https:// doi.org/10.1111/liv.13186.

26. Ledda C, Loreto C, Zammit C, Marconi A, Fago L, Matera S, et al. Noninfective occupational risk factors for hepatocellular carcinoma: A review. Mol Med Rep. 2017;15:511-33. https://doi.org/10.3892/mmr.2016.6046.

27. Choiniere J, Wang L. Exposure to inorganic arsenic can lead to gut microbe perturbations and hepatocellular carcinoma. Acta Pharm Sin B. 2016;6:4269. https://doi.org/10.1016/j.apsb.2016.07.011.

28. Rapisarda V, Loreto C, Malaguarnera M, Ardiri A, Proiti M, Rigano G, et al. Hepatocellular carcinoma and the risk of occupational exposure. World J Hepatol. 2016;8:573-90. https://doi.org/10.4254/wjh.v8.113.573.

29. Badawi AF, Michael MS. Risk factors for hepatocellular carcinoma in Egypt: the role of hepatitis-B viral infection and schistosomiasis. Anticancer Res. 1999;19:4565-9.

30. Omar A, Abou-Alfa GK, Khairy A, Omar H. Risk factors for developing hepatocellular carcinoma in Egypt. Chin Clin Oncol. 2013;2:43. https://doi. org/10.3978/j.issn.2304-3865.2013.11.07.

31. Abou El Azm AR, Yousef M, Mansour N, Awad A, El Dardiry S, Abdel Aziz I. New insights on non-B non-C hepatocellular carcinoma in mid Delta Region, Egypt. J Gastrointest Cancer. 2014;45:276-83. https://doi.org/10. 1007/s12029-013-9573-8.

32. Lehman EM, Soliman AS, Ismail K, Hablas A, Seifeldin IA, Ramadan M, et al. Patterns of hepatocellular carcinoma incidence in Egypt from a populationbased cancer registry. Hepatol Res. 2008;38:465-73. https://doi.org/10.1111/j. 1872-034X.2007.00299.x.

33. Donato F, Tagger A, Gelatti U, Parrinello G, Boffetta P, Albertini A, et al. Alcohol and hepatocellular carcinoma: the effect of lifetime intake and hepatitis virus infections in men and women. Am J Epidemiol. 2002;155: 323-31. https://doi.org/10.1093/aje/155.4.323.

34. Ramadori P, Cubero F, Liedtke C, Trautwein C, Nevzorova Y. Alcohol and hepatocellular carcinoma: adding fuel to the flame. Cancers (Basel). 2017; 9(10). https://doi.org/10.3390/cancers9100130.

35. Abdel-Rahman O, Helbling D, Schöb O, Eltobgy M, Mohamed H, Schmidt J, et al. Cigarette smoking as a risk factor for the development of and mortality from hepatocellular carcinoma: an updated systematic review of 81 epidemiological studies. J Evid Based Med. 2017;10(4):245-54. https://doi. org/10.1111/jebm.12270.

36. Naugler WE, Sakurai T, Kim S, Maeda S, Kim K, Elsharkawy AM, et al. Gender disparity in liver cancer due to sex differences in MyD88-dependent IL-6 production. Science. 2007;317:121-4. https:/doi.org/10.1126/science.1140485.

37. Ma W-L, Lai H-C, Yeh S, Cai X, Chang C. Androgen receptor roles in hepatocellular carcinoma, fatty liver, cirrhosis and hepatitis. Endocr Relat Cancer. 2014;21:R165-82. https://doi.org/10.1530/ERC-13-0283.

38. Kanda $T$, Jiang $X$, Yokosuka $O$. Androgen receptor signaling in hepatocellular carcinoma and pancreatic cancers. World I Gastroenterol. 2014;20:9229-36. https://doi.org/10.3748/wjg.v20.i28.9229.

39. Elghazaly H, Gaballah A, Eldin NB. P-019 Clinic-pathological pattern of hepatocellular carcinoma (HCC) in Egypt. Ann Oncol. 2018;29. https://doi. org/10.1093/annonc/mdy151.018.

40. Lehman EM, Wilson ML. Epidemiology of hepatitis viruses among hepatocellular carcinoma cases and healthy people in Egypt: a systematic review and meta-analysis. Int J Cancer. 2009;124:690-7. https://doi.org/10. 1002/ijc.23937.

41. Larsson SC, Wolk A. Overweight, obesity and risk of liver cancer: a metaanalysis of cohort studies. Br J Cancer. 2007:97:1005-8. https://doi.org/10. 1038/sj.bjc.6603932.

42. Schütte K, Bornschein J, Malfertheiner P. Hepatocellular carcinoma -epidemiological trends and risk factors. Dig Dis. 2009;27:80-92. https://doi. org/10.1159/000218339.

43. Kuper H, Tzonou A, Lagiou P, Mucci LA, Trichopoulos D, Stuver SO, et al. Diet and hepatocellular carcinoma: a case-control study in Greece. Nutr Cancer. 2000;38:6-12. https://doi.org/10.1207/S15327914NC381_2.

44. Polesel J, Talamini R, Montella M, Maso LD, Crovatto M, Parpinel M, et al. Nutrients intake and the risk of hepatocellular carcinoma in Italy. Eur J Cancer. 2007:43:2381-7. https://doi.org/10.1016/j.ejca.2007.07.012.

45. Talamini R, Polesel J, Montella M, Maso LD, Crispo A, Tommasi LG, et al. Food groups and risk of hepatocellular carcinoma: a multicenter case-control study in Italy. Int J Cancer. 2006;119:2916-21. https://doi.org/10.1002/ijc.22267.

46. Sauvaget C, Nagano J, Hayashi M, Spencer E, Shimizu Y, Allen N. Vegetables and fruit intake and cancer mortality in the Hiroshima/Nagasaki Life Span Study. Br J Cancer. 2003;88:689-94. https://doi.org/10.1038/sj.bjc.6600775. 
47. Maheshwari S, Sarraj A, Kramer J, El-Serag HB. Oral contraception and the risk of hepatocellular carcinoma. J Hepatol. 2007;47:506-13. https://doi.org/ 10.1016/j.jhep.2007.03.015.

48. An N. Oral contraceptives use and liver cancer risk. Medicine (Baltimore). 2015;94:e1619. https://doi.org/10.1097/MD.0000000000001619.

49. Shiani A, Narayanan S, Pena L, Friedman M. The role of diagnosis and treatment of underlying liver disease for the prognosis of primary liver cancer. Cancer Control. 2017;24:107327481772924. https://doi.org/10.1177/ 1073274817729240.

50. Salanti G, Southam L, Altshuler D, Ardlie K, Barroso I, Boehnke M, et al. Underlying genetic models of inheritance in established type 2 diabetes associations. Am J Epidemiol. 2009;170:537-45. https://doi.org/10.1093/aje/ kwp145.

51. Florez JC. The Genetics of Type 2 Diabetes: a realistic appraisal in 2008. J. Clin Endocrinol Metab. 2008;93:4633-42. https:/doi.org/10.1210/jc.2008-1345.

52. Li X, Xu H, Gao Y, Pan M, Wang L, Gao P. Diabetes mellitus increases the risk of hepatocellular carcinoma in treatment-naïve chronic hepatitis $C$ patient in China. Medicine (Baltimore). 2017;96:e6508. https://doi.org/10.1097/MD. 0000000000006508.

53. Hsu HC, Peng SY, Lai PL, Sheu JC, Chen DS, Lin LI, et al. Allelotype and loss of heterozygosity of p53 in primary and recurrent hepatocellular carcinomas. A study of 150 patients. Cancer. 1994;73:42-7. https://doi.org/ 10.1002/1097-0142(19940101)73:1<42::aid-cncr2820730109>3.0.co;2-d.

54. Bakir AS. and A-EZA. Is diabetes mellitus a risk factor for hepatocellular carcinoma in Egyptian patients. J Am Sci. 2012;8:353-8.

55. Morsy KH, Mahmoud Saif-Al-Islam EMI. Hepatocellular carcinoma in Upper Egypt: a retrospective study. ARC J Hepatol Gastroenterol. 2018;3:8-17.

56. Hjalgrim H, Frisch M, Ekbom A, Kyvik KO, Melbye M, Green A. Cancer and diabetes - a follow-up study of two population-based cohorts of diabetic patients. J Intern Med. 1997;241:471-5.

57. Hassan M, Hwang L-Y, Hatten CJ, Swaim M, Li D, Abbruzzese JL, et al. Risk factors for hepatocellular carcinoma: Synergism of alcohol with viral hepatitis and diabetes mellitus. Hepatology. 2002;36:1206-13. https://doi. org/10.1053/jhep.2002.36780.

58. Adami H-O, Chow W-H, Nyren O, Berne C, Linet MS, Ekbom A, et al. Excess risk of primary liver cancer in patients with diabetes mellitus. J Natl Cancer Inst. 1996;88:1472-7. https://doi.org/10.1093/jnci/88.20.1472.

59. Nalbantoglu ILK, Brunt EM. Role of liver biopsy in nonalcoholic fatty liver disease. World J Gastroenterol. 2014;20:9026-37. https://doi.org/10.3748/wjg.v20.i27.9026.

60. Yatsuji S, Hashimoto E, Tobari M, Taniai M, Tokushige K, Shiratori K. Clinical features and outcomes of cirrhosis due to non-alcoholic steatohepatitis compared with cirrhosis caused by chronic hepatitis C. J Gastroenterol Hepatol. 2009;24:248-54. https://doi.org/10.1111/j.1440-1746.2008.05640.x.

61. Neuschwander-Tetri BA. Nonalcoholic steatohepatitis and the metabolic syndrome. The Am J Med Sci. 2005;330:326-35.

62. Hazari YM, Bashir A, Habib M, Bashir S, Habib H, Qasim MA, et al. Alpha-1antitrypsin deficiency: genetic variations, clinical manifestations and therapeutic interventions. Mutation Research/Reviews in Mutat Res. 2017; 773:14-25. https://doi.org/10.1016/j.mrrev.2017.03.001.

63. Elzouki AN, Eriksson S. Risk of hepatobiliary disease in adults with severe alpha 1-antitrypsin deficiency (PiZZ): is chronic viral hepatitis B or C an additional risk factor for cirrhosis and hepatocellular carcinoma? Eur J Gastroenterol Hepatol. 1996;8:989-94.

64. Bosetti C, Turati F, La Vecchia C. Hepatocellular carcinoma epidemiology. Best Pract R Clin Gastroenterol. 2014;28:753-70. https://doi.org/10.1016/j. bpg.2014.08.007.

65. Dragani TA. Risk of HCC: Genetic heterogeneity and complex genetics. J Hepatol. 2010;52:252-7. https://doi.org/10.1016/j.jhep.2009.11.015.

66. Liu Y, Wu F. Global burden of aflatoxin-induced hepatocellular carcinoma: a risk assessment. Environ Health Perspect. 2010;118:818-24. https://doi.org/ 10.1289/ehp.0901388.

67. Polychronaki N, Wild CP, Mykkänen H, Amra H, Abdel-Wahhab M, Sylla A, et al. Urinary biomarkers of aflatoxin exposure in young children from Egypt and Guinea. Food Chem Toxicol. 2008;46:519-26. https://doi.org/10.1016/j. fct.2007.08.034.

68. Turner PC, Loffredo C, El Kafrawy S, Ezzat S, Eissa SAL, El Daly M, et al. Pilot survey of aflatoxin-albumin adducts in sera from Egypt. Food Addit Contam Part A Chem Anal Control Expo Risk Assess. 2008;25:583-7. https://doi.org/ 10.1080/02652030701713939.

69. Anwar W, Khaled H, Amra H, Elnezami H, Loffredo C. Changing pattern of hepatocellular carcinoma (HCC) and its risk factors in Egypt: Possibilities for prevention. Mutat Res. 2008;659:176-84. https://doi.org/10.1016/j.mrrev.2008. 01.005.

70. Rahman El-Zayadi A, Abaza H, Shawky S, Mohamed MK, Selim OE, Badran HM. Prevalence and epidemiological features of hepatocellular carcinoma in Egypt—a single center experience. Hepatol Res. 2001;19:170-9.

71. IARC Working Group on the Evaluation of Carcinogenic Risks to Humans. Some traditional herbal medicines, some mycotoxins, naphthalene and styrene. IARC Monogr Eval Carcinog Risks Hum. 2002;82:1-556.

72. Wang H, Liao P, Zeng SX, Lu H. It takes a team: a gain-of-function story of p53R249S. J Mol Cell Biol. 2019;11:277-83. https://doi.org/10.1093/jmcb/mjy086.

73. Hosny G, Farahat N, Tayel H, Hainaut P. Ser-249 TP53 and CTNNB1 mutations in circulating free DNA of Egyptian patients with hepatocellular carcinoma versus chronic liver diseases. Cancer Lett. 2008;264:201-8. https:// doi.org/10.1016/j.canlet.2008.01.031.

74. Jiao J, Niu W, Wang Y, Baggerly K, Ye Y, Wu X, et al. Prevalence of Aflatoxinassociated TP53R249S mutation in hepatocellular carcinoma in Hispanics in South Texas. Cancer Prev Res (Phila). 2018;11:103-12. https://doi.org/10. 1158/1940-6207.CAPR-17-0235.

75. Ungtrakul T, Mahidol C, Chun-on P, Laohapand C, Siripongsakun S, Worakitsitisatorn A, et al. Hepatocellular carcinoma screening and surveillance in 2293 chronic hepatitis B patients in an endemic area. World J. Gastroenterol. 2016;22:7806-12. https://doi.org/10.3748/WJG.V22.I34.7806.

76. Yang JD, Roberts LR. Hepatocellular carcinoma: A global view. Nat Rev Gastroenterol Hepatol. 2010;7:448-58. https://doi.org/10.1038/nrgastro.2010.100.

77. Esmat G, El-Sayed MH, Hassany M, Doss W, Waked I. National Committee for the control of viral hepatitis. One step closer to elimination of hepatitis C in Egypt. Lancet Gastroenterol Hepatol. 2018;3:665. https:/doi.org/10.1016/ S2468-1253(18)30268-1.

78. El Kassas M, Funk AL, Salaheldin M, Shimakawa Y, Eltabbakh M, Jean K, et al. Increased recurrence rates of hepatocellular carcinoma after DAA therapy in a hepatitis C-infected Egyptian cohort: A comparative analysis. J Viral Hepat. 2018;25:623-30. https://doi.org/10.1111/jvh.12854.

79. Lleo A, Aglitti A, Aghemo A, Maisonneuve P, Bruno S, Persico M, et al. Predictors of hepatocellular carcinoma in HCV cirrhotic patients treated with direct acting antivirals. Dig Liver Dis. 2019;51:310-7. https://doi.org/10.1016/j. dld.2018.10.014

80. Guarino M, Sessa A, Cossiga V, Morando F, Caporaso N, Morisco F, et al. Direct-acting antivirals and hepatocellular carcinoma in chronic hepatitis C: a few lights and many shadows. World J. Gastroenterol. 2018;24:2582-95. https://doi.org/10.3748/wjg.v24.i24.2582.

81. El Kassas M, Elbaz T, Salaheldin M, Abdelsalam L, Kaseb A, Esmat G. Impact of treating chronic hepatitis $C$ infection with direct-acting antivirals on the risk of hepatocellular carcinoma: the debate continues - a mini-review. J Adv Res. 2019;17:43-8. https://doi.org/10.1016/j.jare.2019.03.001.

82. Dimitroulis D, Damaskos C, Valsami S, Davakis S, Garmpis N, Spartalis E, et al. From diagnosis to treatment of hepatocellular carcinoma: an epidemic problem for both developed and developing world. World J Gastroenterol. 2017;23:5282-94. https://doi.org/10.3748/wjg.v23.i29.5282.

83. Hartke J, Johnson M, Ghabril M. The diagnosis and treatment of hepatocellular carcinoma. Semin Diagn Pathol. 2017;34:153-9. https://doi. org/10.1053/j.semdp.2016.12.011.

84. Henderson JM, Sherman M, Tavill A, Abecassis M, Chejfec G, Gramlich T. AHPBA/AJCC consensus conference on staging of hepatocellular carcinoma: consensus statement. HPB (Oxford). 2003;5:243-50. https://doi.org/10.1080/ 13651820310015833

85. Marrero JA, Fontana RJ, Barrat A, Askari F, Conjeevaram HS, Su GL, et al. Prognosis of hepatocellular carcinoma: comparison of 7 staging systems in an American cohort. Hepatology. 2005;41:707-16. https://doi.org/10.1002/ hep.20636.

86. Sheta E, El-Kalla F, El-Gharib M, Kobtan A, Elhendawy M, Abd-Elsalam S, et al. Comparison of single-session transarterial chemoembolization combined with microwave ablation or radiofrequency ablation in the treatment of hepatocellular carcinoma. Eur J Gastroenterol Hepatol. 2016;28:1198-203. https://doi.org/10.1097/MEG.0000000000000688.

87. Negm O, Abou Saif S, El Gharib M, Yousef M, Abd-Elsalam S. Role of lowmolecular-weight heparins in prevention of thromboembolic complication after transarterial chemoembolization in hepatocellular carcinoma. Eur J Gastroenterol Hepatol. 2017;29:317-21. https://doi.org/10.1097/MEG. 0000000000000790.

88. Abdelfattah AAM, Rizk F, Hawash N, Hanafy A, El-kalla F, Abd-Elsalam S. Randomized trial of preoperative administration of oral pregabalin for 
postoperative analgesia in patients scheduled for radiofrequency ablation of focal lesions in the liver. Int J Hyperthermia. 2018;34:1367-71. https://doi. org/10.1080/02656736.2018.1424946.

89. Elhefnawi M, Salah Z, Soliman B. The promise of miRNA replacement therapy for Hepatocellular carcinoma. Curr Gene Ther. 2019;19. https://doi. org/10.2174/1566523219666191023101433.

90. Golabi P, Fazel S, Otgonsuren M, Sayiner M, Locklear CT, Younossi ZM. Mortality assessment of patients with hepatocellular carcinoma according to underlying disease and treatment modalities. Medicine (Baltimore). 2017;96: e5904. https://doi.org/10.1097/MD.0000000000005904.

91. Zeeneldin AA, Salem SE, Darwish AD, El-Gammal MM, Hussein MM, Saadeldin M. Untreated hepatocellular carcinoma in Egypt: outcome and prognostic factors. J Hepatocell Carcinoma. 2015;2:3-9. https://doi.org/10. 2147/JHC.S73828.

92. Abdelaziz AO, Elbaz TM, Shousha HI, Ibrahim MM, Rahman El-Shazli MA, Abdelmaksoud AH, et al. Survival and prognostic factors for hepatocellular carcinoma: an Egyptian multidisciplinary clinic experience. Asian Pac J Cancer Prev. 2014;15:3915-20. https://doi.org/10.7314/apjcp.2014.15.9.3915.

93. Waziry R, Gomaa A, Waked I, Dore GJ. Determinants of survival following hepatocellular carcinoma in Egyptian patients with untreated chronic HCV infection in the pre-DAA era. Arab J Gastroenterol. 2018;19:26-32. https:// doi.org/10.1016/j.ajg.2018.02.004.

94. Chen K-W, Ou T-M, Hsu C-W, Horng C-T, Lee C-C, Tsai Y-Y, et al. Current systemic treatment of hepatocellular carcinoma: a review of the literature. World J Hepatol. 2015;7:1412. https://doi.org/10.4254/wjh.v7.i10.1412.

95. Yim HJ, Suh SJ, Um SH. Current management of hepatocellular carcinoma: an Eastern perspective. World J. Gastroenterol. 2015;21:3826-42. https://doi. org/10.3748/wjg.v21.i13.3826

96. Kudo M. Targeted and immune therapies for hepatocellular carcinoma: predictions for 2019 and beyond. World J Gastroenterol. 2019;25:789-807. https://doi.org/10.3748/wjg.v25.i7.789.

97. Schütte K, Balbisi F, Malfertheiner P. Prevention of Hepatocellular Carcinoma. Gastrointest Tumors. 2016;3:37-43. https://doi.org/10.1159/000446680.

98. Singal AG, El-Serag HB. Hepatocellular carcinoma from epidemiology to prevention: translating knowledge into practice. Clin Gastroenterol Hepatol. 2015;13:2140-51. https://doi.org/10.1016/j.cgh.2015.08.014.

99. Giacomin A, Cazzagon N, Sergio A, Vanin V, Farinati F. Hepatitis B virusrelated hepatocellular carcinoma. Eur J Cancer Prev. 2011;20:381-8. https:// doi.org/10.1097/CEJ.0b013e328346399b.

100. Ferenci $P$, Fried M, Labrecque D, Bruix J, Sherman M, Omata M, et al. World Gastroenterology Organisation Guideline. Hepatocellular carcinoma (HCC): a global perspective. J Gastrointestin Liver Dis. 2010;19:311-7.

101. Saleh DA, Amr S, Jillson IA, Wang JH, Crowell N, Loffredo CA. Preventing hepatocellular carcinoma in Egypt: results of a Pilot Health Education Intervention Study. BMC Res Notes. 2015;8:384. https://doi.org/10.1186/ s13104-015-1351-1.

102. Hassany SM, Moustafa EFA, El Taher M, Abdeltwab AA, Blum HE. Screening for hepatocellular carcinoma by Egyptian physicians. World J Gastrointest Oncol. 2015;7:161-71. https://doi.org/10.4251/wjgo.v7.i9.161.

103. Zucman-Rossi J, Villanueva A, Nault J-C, Llovet JM. Genetic Landscape and Biomarkers of Hepatocellular Carcinoma. Gastroenterology. 2015;149:12261239.e4. https://doi.org/10.1053/j.gastro.2015.05.061.

104. Ally A, Balasundaram M, Carlsen $R$, Chuah E, Clarke A, Dhalla N, et al. Comprehensive and integrative genomic characterization of hepatocellular carcinoma. Cell. 2017;169:1327-1341.e23. https://doi.org/10.1016/j.cell.2017.05.046.

105. Calderaro J, Couchy G, Imbeaud S, Amaddeo G, Letouzé E, Blanc J-F, et al. Histological subtypes of hepatocellular carcinoma are related to gene mutations and molecular tumour classification. J Hepatol. 2017;67:727-38. https://doi.org/10.1016/j.jhep.2017.05.014.

106. Alboraie M, Youssef N, Sherief AF, Afify S, Wifi M-N, Omran D, et al. Egyptian liver library: an indexed database for liver disease evidence in Egypt. Arab J Gastroenterol. 2019;20:109-13. https://doi.org/10.1016/j.ajg.2019.05.004.

107. El-Gebaly F, Abou-saif S, Elkadeem M, Helmy A, Abd-Elsalam S, Yousef M, et al. Study of serum soluble programmed death ligand 1 as a prognostic factor in hepatocellular carcinoma in Egyptian Patients. Curr Cancer Drug Targets. 2019;19(11):896-905. https://doi.org/10.2174/ 1568009619666190718141647.

108. Elwan N, Salem ML, Kobtan A, El-Kalla F, Mansour L, Yousef M, et al. High numbers of myeloid derived suppressor cells in peripheral blood and ascitic fluid of cirrhotic and HCC patients. Immunol Invest. 2018;47:169-80. https:// doi.org/10.1080/08820139.2017.1407787.
109. McNeil C. NCl-MATCH Launch Highlights New Trial Design in PrecisionMedicine Era. J Natl Cancer Inst. 2015;107:djv193. https://doi.org/10.1093/ jnci/djv193.

\section{Publisher's Note}

Springer Nature remains neutral with regard to jurisdictional claims in published maps and institutional affiliations.

\section{Submit your manuscript to a SpringerOpen ${ }^{\circ}$ journal and benefit from:}

- Convenient online submission

- Rigorous peer review

- Open access: articles freely available online

- High visibility within the field

- Retaining the copyright to your article

Submit your next manuscript at $\boldsymbol{\nabla}$ springeropen.com 